\title{
Potencial Cognitivo P300 em pacientes com lesão isquêmica do hemisfério direito $* * * *$
}

\author{
Cognitive Potential - P300 in patients with right hemisphere \\ ischemic lesion
}

Fernanda Cristina Leite Magliaro* Sandro Luiz de Andrade Matas** Carla Gentile Matas***

*Fonoaudióloga. Doutora em Ciências pelo Programa de Pós-Graduação em Ciências da Reabilitação do Departamento de Fisioterapia, Fonoaudiologia e Terapia Ocupacional da Faculdade de Medicina da Universidade de São Paulo (FMUSP). Endereço para correspondência: Rua Deolinda Rodrigues, 171 - Apto. 44 Bloco A - São Paulo - SP CEP 05372-100 (fe_fono@yahoo.com.br)

**Neurologista. Doutor em Neurologia pelo Programa de Pós-Graduação do Departamento de Neurologia e Neurocirurgia da Universidade Federal de São Paulo (Unifesp). Professor Afiliado do Departamento de Medicina da Unifesp.

***Fonoaudióloga. Doutora em Ciências dos Distúrbios da Comunicação Humana Campo Fonoaudiológico - Programa de PósGraduação em Distúrbios da Comunicação Humana da Unifesp. Professora Assistente Doutora do Curso de Fonoaudiologia da FMUSP.

****Trabalho Realizado no Laboratório de Investigação Fonoaudiológica em Potenciais Evocados Auditivos do Departamento de Fisioterapia, Fonoaudiologia e Terapia Ocupacional da FMUSP.

Artigo Original de Pesquisa

Artigo Submetido a Avaliação por Pares

Conflito de Interesse: não

\begin{abstract}
Background: cognitive potential - P300 assessment in individuals with right hemisphere ischemic lesion due to ischemic stroke. Aim: to characterize the cognitive potential - P300 in right-handed individuals with right hemisphere ischemic lesion, and to compare such data to those obtained in normal individuals. Method: anamnesis, conventional audiologic assessment and cognitive potential (P300) were carried out in 17 subjects with right hemisphere lesions (research group) and in 25 normal individuals (control group), aged between 20 and 70 years. Results: in the qualitative analysis of the P300 data, there was no statistically significant difference between groups for the normal result. In the quantitative analysis, there was a statistically significant difference between groups in terms of P300 wave latency, with the research group presenting higher latencies. In addition, there was a trend for a statistically significant difference between the right and left ears in the research group - increased P300 wave latency in the right ear. Conclusion: right-handed individuals with right hemisphere lesion and normal hearing presented electrophysiological hearing results indicative of central auditory nervous system deficits. Alterations were observed in regions generating this potential (cortical and subcortical areas). Hearing difficulties were not perceived by these individuals, suggesting that this signal can probably be related to an auditory heminegligence. Further studies that evaluate the central auditory pathway of individuals with right hemisphere ischemic lesion are needed in order to better characterize the electrophysiological findings. Key Words: Auditory Evoked Potentials; P300 Event-Related Potentials; Stroke; Brain Ischemia.
\end{abstract}

\section{Resumo}

Tema: avaliação do potencial cognitivo P300 em indivíduos com lesão de hemisfério direito provocada por acidente vascular cerebral isquêmico. Objetivo: caracterizar os achados do potencial cognitivo P300 em indivíduos destros com lesão isquêmica do hemisfério cerebral direito, bem como comparar seus resultados aos obtidos em indivíduos normais. Método: foram realizadas anamnese, avaliação audiológica convencional e potencial cognitivo (P300), em 17 indivíduos com lesão do hemisfério direito (grupo pesquisa) e 25 normais (grupo controle), com idades entre 20 e 70 anos. Resultados: na análise dos dados qualitativos do P300, não houve diferença estatisticamente significante entre os grupos para o resultado normal. Para a análise dos dados quantitativos, ocorreu diferença estatisticamente significante entre os grupos com relação à latência da onda $\mathrm{P} 300$, sendo que o grupo pesquisa apresentou latência maior. Além disso, houve uma tendência estatisticamente significante entre as orelhas direita e esquerda dentro do grupo pesquisa, mostrando aumento de latência da onda P300 na orelha direita. Conclusão: Indivíduos destros com lesão de hemisfério direito e limiares auditivos normais, apresentaram resultados eletrofisiológicos da audição indicativos de déficit no sistema nervoso auditivo central. Foram observados comprometimentos nas regiões geradoras deste potencial (áreas subcorticais e corticais). Dificuldades auditivas não foram percebidas pelos indivíduos, sugerindo que, provavelmente tal sinal possa estar relacionado à uma heminegligência auditiva. Tornam-se necessários mais estudos que avaliem a via auditiva central destes indivíduos para uma melhor caracterização dos achados eletrofisiológicos.

Palavras-Chave: Potenciais Evocados Auditivos; Potencial Evocado P300; Acidente Cerebral Vascular; Isquemia Encefálica.

Recebido em 01.07.2009.

Revisado em 06.10.2009.

Aceito para Publicação em 16.10.2009.

Referenciar este material como:

1 Magliaro FCL, Matas SLA, Matas CG. Cognitive Potential - P300 in patients with right hemisphere ischemic lesion (original title: Potencial Cognitivo P300 em $\sum 3$ pacientes com lesão isquêmica do hemisfério direito). Pró-Fono Revista de Atualização Científica. 2009 out-dez;21(4):285-90. 


\section{Introduction}

The ischemic cerebral vascular accident (ICVA) is a neurological disease characterized by the interruption of the blood flow through the brain. It may result in cellular lesions and impairments to the neurological functions depending on the lesion's localization and extension (motor, sensorial, cognitive, perceptual, language and others) (1). Researches have shown disorders of the central auditory process abilities in patients with right hemisphere lesions. The impairments are mainly related to the sound location (2-6) and some of these findings were associated to a possible auditory hemi-negligence.

Auditory evoked potentials (AEPs) are objective methods used to evaluate the auditory central pathway (from the acoustic nerve to the cerebral cortex) response to acoustic stimuli (7). The cognitive potential - P300 is an endogenous potential that occurs $300 \mathrm{~ms}$ after the acoustic stimulation (8) and its generation involves auditory discrimination and memory processes (9).

Individuals with right hemisphere lesions may present hemineglect to sensorial stimuli contralateral to the injured hemisphere (10) and thus, auditory processing disorders may occur without being detected by them. Thus, the use of objective methods to identify the central auditory pathway impairments is necessary to provide the adequate intervention to reduce the impact on the individual's life quality.

This way, the objective of this study was to characterize the cognitive potential P300 findings in right- handed individuals with ischemic lesions on the right cerebral hemisphere and to compare the results to the obtained in normal individuals.

\section{Method}

The present research consists of a transversal, prospective, observational and descriptive study approved by the research ethic committee of both of the institutions involved (Cappesq-HCFM-USP 0312/08 and HU-USP 810/08). All the subjects signed the consent form before the assessment.

\section{Subjects}

Participated in the study 42 right-handed individuals with ages between 20 and 70 years, divided in two groups: research group (RG) comprised of 17 subjects (11 females and 6 males) with ischemic lesions of the right cerebral hemisphere (mean age 48 years); and control group (CG) comprised by 25 right-handed individuals (21 females and 4 males) without prior neurological or psychiatric disorders or hearing and language complaints (mean age 34 years).

The individuals of the RG were selected from a list of patients of the University Hospital-University of Sao Paulo (HU-USP) and of the Clinical Hospital of the School of Medicine- University of São Paulo (HC-FMUSP). Inclusion criteria for this group were: ischemic lesion of the right cerebral hemisphere (confirmed by magnetic resonance or computerized tomography) after a single ischemic cerebral vascular accident (ICVA) over six months; scores between 0 and 3 on the rankin modified scale; absence of brain stem or cerebellum lesions (confirmed by image exams), absence of previous neurological condition (cerebral vascular conditions or infectious deceases involving central nervous system, dementia processes, Parkinson or Alzheimer decease, epilepsy or others).

\section{Procedures}

The interview, screening and rankin modified (11) scale protocols (the last two just to the RG) were used to select the research subjects.

The conventional audiological assessment was comprised by the following procedures:

- Visual inspection of the external acoustic canal with Heine otoscope;

- Acoustic immittance measures (tympanometry and research of the ipsilateral acoustic reflexes in the frequencies of 500,1000, 200 and $400 \mathrm{~Hz}$ ) with a Grason-Stadler GSI-33 middle ear analyzer (ANSI s3.39-1987);

- Pure tone audiometry (frequencies from 250 to $8000 \mathrm{~Hz}$ ), speech recognition threshold (SRT) and speech recognition index (SRI) with GSI-61 and GSI68 Grason-Stadler audiometers, supra aural hearing phones TDH-50 (ANSI S3.1989 and IEC-1988) and a soundproof booth (ANSI S3.1-1991).

The P300 assessment was conducted after the identification of normal hearing thresholds (mean of 500, 1000 and $2000 \mathrm{~Hz}$ under $25 \mathrm{~dB}$ HL). The individual was sited on a reclining chair inside an acoustically and electrically treated room. The skin (front, mastoid and scalp) was cleaned with abrasive paste and the surface electrodes were fixed with electrolytic paste and tape. The acoustic stimuli were presented through supra-aural headphones and the impedance values of the electrodes should remain under $5 \mathrm{kOhms}$. The parameters used were: 
mono-aural presentation of the tone-burst stimulus at $75 \mathrm{~dB}$ HL with a presentation rate of 1.1 stimuli per second, with a total of 300 stimuli. The frequent stimuli ( 80 to $85 \%$ ) were presented at $1000 \mathrm{~Hz}$ and the rare (15 to $20 \%)$ at $1500 \mathrm{~Hz}$. The electrodes were positioned on the vertex $(\mathrm{Cz})$, on the right and left mastoids (A1 and A2) and on the forehead (Fpz), according to the International Electrode System (IES) 10-20 (12). Responses were collected with a gain of 15.000 and filtered from 1 to $30 \mathrm{~Hz}$ and recorded over $512 \mathrm{~ms}$ post-stimulation time period. Just one register of each side (ipsilateral) was recorded. The individual was instructed to maintain the attention focused on the rare stimulus, which occurred randomly within a series of frequent stimuli, and to count the number of times the rare stimulus occurred. By the end of the stimuli presentation to each ear the individual was asked about the counting and the answer was compared to the total registered by the equipment. This way it was possible to confirm that the individual participated correctly in the activity and kept the attention on the rare stimulus (13-14).

Data classification

The P300 wave was identified after the subtraction between the curves of the rare and frequent stimulus (of the same ear). The latency values of the P300 wave were determined for each individual. This way each individual was classified as normal or altered when at least one ear presented abnormal results when compared with the normative values proposed by the literature (15). The altered results were classified as: delayed; absent and both (delayed and absent in the same individual).

\section{Statistical method}

The analysis of the qualitative data was conducted through the comparison of the normal and altered results per ear (within group) and per individual (within and between groups). The observed types of disorders were also compared within and between groups. The analysis of the quantitative data was conducted through the comparison of the P300 latency values between groups and within groups (right ear versus left ear).

Wilcoxon test, Equality test of two proportions, Mann-Whitney test and Average confidence interval were used for statistical analysis of the data. The significance level adopted was 0.05 (5\%). All the confidence intervals were built with a statistical safety margin of $95 \%$.

\section{Resultados}

Quantitative data analysis

The first comparison analyzed the P300 latency of right and left ears in each group. In Table 1 there were no statistically significant differences between the P300 latencies of both ears in the CG. However, there was a tendency to statistical significance in the difference between ears in RG.

We then determined the average for each group and compared the P300 latencies between groups. Table 2 shows statistically significant differences between the P300 latency waves of the two groups. RG presented higher mean latency values than CG.

Qualitative data analysis.

The normal and altered results of right and left ears were compared to each group. The results have shown that there is no statistically significant difference in the CG (p-value 1.000) and RG (p-value 0.310).

The distribution of normal and altered P300 results (per individual) in both RG and CG will be presented. It was observed in Table 3 that there was a statistically significant difference regarding to the occurrence of normal and altered results within groups but not between groups. All individuals of CG presented normal results and just one individual of $\mathrm{RG}$ presented altered result (delay). 
TABLE 1. P300 latency comparison between right and left ears in the control and research groups.

\begin{tabular}{ccccc}
\hline \multirow{2}{*}{ P300 latency } & \multicolumn{2}{c}{ Control } & \multicolumn{2}{c}{ Research } \\
\cline { 2 - 5 } & RE & LE & RE & LE \\
\hline Average & 305.8 & 308.9 & 350.6 & 337.2 \\
\hline Mean & 300 & 298 & 356 & 332 \\
\hline Standard Deviation & 29.3 & 30.7 & 25.3 & 23.9 \\
\hline Q1 & 284 & 292 & 332 & 326 \\
\hline Q3 & 330 & 326 & 372 & 354 \\
\hline N & 25 & 25 & 17 & 17 \\
\hline CI & 11.5 & 12.0 & 12.0 & 11.4 \\
\hline p-value & & 0.411 & & $0.056 \#$ \\
\hline
\end{tabular}

\# = tendency to statistical signific ance, $\mathrm{Q} 1$ = first quarter, $\mathrm{Q} 3=$ third quarter

$\mathrm{N}=$ sample size, $\mathrm{CI}=$ confidence interval, $\mathrm{RE}=$ Right Ear, LE = Left Ear

P300 = Cognitive Potential

TABLE 2. P300 laten cy comparison between groups

\begin{tabular}{ccc}
\hline \multirow{2}{*}{ P300 } & \multicolumn{2}{c}{ Latency $(\mathbf{m s})$} \\
\cline { 2 - 3 } & Control & Research \\
\hline Average & 307.4 & 343.9 \\
\hline Mean & 298.0 & 347.0 \\
\hline Standard Deviation & 29.8 & 25.2 \\
\hline Q1 & 287.3 & 326.5 \\
\hline Q3 & 329.5 & 361.5 \\
\hline N & 50 & 8.46 \\
\hline CI & 8.25 & \\
\hline p-value & & $<0.001 *$ \\
\hline
\end{tabular}

* p- value statistically significant, Q1 = first quarter, Q3 = third quarter

$\mathrm{N}=$ sample size, $\mathrm{IC}=$ confidence interval, $\mathrm{RE}=\mathrm{Right}$ Ear

LE $=$ Left Ear, P300 = Cognitive Potential

TABLE 3. Distribution of normal and altered results in the P300 in control and research groups

\begin{tabular}{|c|c|c|c|c|c|}
\hline \multirow{2}{*}{ P300 } & \multicolumn{2}{|c|}{ Control } & \multicolumn{2}{|c|}{ Research } & \multirow{2}{*}{ p-value } \\
\hline & $\mathrm{N}$ & $\%$ & $\mathrm{~N}$ & $\%$ & \\
\hline Altered & 0 & $0 \%$ & 1 & $5.9 \%$ & \multirow{2}{*}{0.220} \\
\hline Normal & 25 & $100 \%$ & 16 & $94.1 \%$ & \\
\hline p-value & \multicolumn{2}{|c|}{$<0.001 *$} & \multicolumn{2}{|c|}{$<0.001^{*}$} & \\
\hline
\end{tabular}

* p- value statistically significant

$\mathrm{N}=$ sample size

$\mathrm{P} 300=$ Cognitive Potential 


\section{Discussion}

Comparing the latency of the P300 wave of both ears (Table 1) a tendency to statistical difference was observed in the RG, with longer latencies to right ear (RE) than to the left ear (LE). It was also observed that the RG's RE average latency was higher than the CG's $\mathrm{RE}$ average latency. It should be considered that, according to the assessment protocol, the ipsilateral pathway was studied, that is, the P300 wave was generated in the RH when the RE received the stimulus. Accordingly, the P300 wave was generated in the LH when the LE received the stimulus.

Frizzo et al. (16) didn't find differences on the P300 in right and left hemispheres of normal hearing individuals. This way, the results presented by the $\mathrm{CG}$ of this research agree with them in what refers to the P300 latency wave.

With respect to the results presented by the group with right hemisphere lesion (RHL) it can be inferred that the abnormal neural activity, due to a cerebral lesion, may have caused the differences of the P300 latencies of RH and LH in these subjects.

It was observed in Table 2 that the individuals with (RHL) presented longer latencies of the P300 wave then normal individuals. Studies reported delay or absence of P300 wave in individuals with encephalic lesions (17-18). Individuals with neocortical lesions performed correctly the task of counting the rare stimulus. This way, this study determined that the $\mathrm{P} 300$ is susceptible to neocortical lesions and that also reflects the cognitive processing, not just the discrimination of stimuli (17).

The results of the present study agree with the findings of the mentioned research in what refers to the delay of the P300 wave in individuals with cerebral lesion and also to the fact that the individuals performed correctly the task of counting the rare stimulus.

In what refers to the analysis of qualitative data, Table 3 shows that there was no significant statistical difference between the groups. All CG subjects presented normal results and just one individual with RHL presented altered results (delay of the P300 latency wave). Considering that most of the individuals with RHL presented latency values within the normality rates, it is possible to suggest the hypothesis that there was interference of neural plasticity. Once the auditory assessment was conducted after at least six months after the lesion, there was enough time to allow the reorganization of neural structures of the Central Nervous System(CNS).

The analysis of the qualitative and quantitative data has shown divergent results. The qualitative data pointed out that individuals with RH lesions do not present altered $\mathrm{P} 300$ results while the quantitative results indicated differences between the groups in what refers to the P300 latency wave, suggesting a generation deficit of this wave to RG. This discrepancy is probably related to the method used to both analyses. In the qualitative analysis there is a wide normality range, where it would be necessary a longer latency or wave absence to identify the disorder.

Once the electrophysiological assessment were conducted after the VCA's acute phase, this time interval may have been enough to promote structural and/or functional changes in the CNS. This way, another interpretation to the differences observed in the qualitative and quantitative results indicates that: the qualitative analysis has shown this neural reorganization once the identified $\mathrm{P} 300$ waves within the normality range; on the other hand, the quantitative analysis suggests that although the $\mathrm{RH}$ has enough neural activity to generate a P300 wave, its latency indicates that the acoustic stimulus processing in impaired/slowed in that region.

$\mathrm{P} 300$ is an endogenous potential and therefore is adequately generated as long as the individual is capable of focusing the attention on the rare stimulus that are presented within a series of frequent stimulus (19). Since in the present study the subject performed satisfactorily in this task, the electrophysiological data reinforces the hypothesis that the RH lesion may have resulted on a acoustic information processing deficit by that hemisphere.

Some researches have shown central auditory processing disorders by means of behavior tests applied to individuals with cortical/sub-cortical lesions, testing especially sound localization (2-5), temporal resolution (20-21), frequency, intensity and duration patterns (6). Taking these studies into account we may suggest that our research indicated auditory processing disorder in individuals with $\mathrm{RH}$ lesion, detected by an electrophysiological test.

Häusler and Levine (22), in their revision, reported that the CVA probably affects the Auditory Central Nervous System (ACNS), resulting in different types of auditory disorders. Nevertheless, the acoustic symptoms may be so slight that most individuals do not perceive them. Therefore the authors state that the identification of these disorders is only possible through sophisticated acoustic tests, as the electrophysiological and behavioral tests.

The presence of RH sub-cortical/cortical alterations in individuals with RH ischemic lesions, identified through the P300 and not consciously perceived by them indicates the possibility of an acoustic hemineglect in this population. Finally, the results of the present study have shown that the cognitive potential $\mathrm{P} 300$ is a useful tool to the identification of ACNS alterations in these individuals. 


\section{Conclusion}

Individuals with ischemic lesion of the right hemisphere present cognitive potential P300 alterations, suggesting: disorders of the central auditory processing; functional and/or structural disorders in the cortical/sub-cortical regions of the right hemisphere that generates this potential.
Due to the alterations evidenced by the P300 and to the fact that the individuals do not perceive them, we may suggest a possible acoustic hemineglect in patients with RH lesions. Other studies are necessary to assess the central auditory pathway in these individuals to determine a better characterization of the electrophysiological findings.

\section{References}

1- O'Sullivan SB. Acidente Vascular Encefálico. In: O'Sullivan SB, Schimitz TJ, org. Fisioterapia: Avaliação e Tratamento. $2^{a}$ ed. São Paulo: Manole; 1993. p.519-81.

2- Bisiach E, Cornacchia L, Sterzi R, Vallar G. Disorders of perceived auditory lateralization after lesions of the right hemisphere. Brain. 1984;107:37-52.

3- Tanaka H, Hachisuka K, Ogata H. Sound lateralisation in patients with left or right cerebral hemispheric lesions: relation with unilateral visuospatial neglect. J Neurol Neurosurg Psychiatry. 1999;67(4):481-6.

4- Bellmann A, Meuli R, Clarke S. Two types of auditory neglect. Brain. 2001;124:676-87.

5- Adriani M, Bellmann A, Meuli R, Fornari E, Frischknecht $\mathrm{R}$, Bindschaedler $\mathrm{C}$, et al. Unilateral hemispheric lesions disrupt parallel processing within the contralateral intact hemisphere: na auditory fMRI study. Neuroimage. 2003;20 supl.1:S66-S74.

6- Biedermann F, Bungert P, Dorrscheidt GJ, Von Cramon DY, Rubsamen R. Central auditory impairment in unilateral diencephalic and telencephalic lesions. Audiology and neurotology. 2008;13:123-44.

7- Junqueira CAO, Frizzo ACF. Potenciais evocados auditivos e curta, média e londa latência. In: Aquino AMCM, org. Processamento auditivo - Eletrofisiologia e Psicoacústica. São Paulo: Lovise; 2002. p.63-85.

8- Sutton S, Braren M, Zubin J, John ER. Evoked potential correlates of stimulus uncertainty. Science. 1965;150:11878 .

9- Kraus N, McGee T. Potenciais Auditivos Evocados de Longa Latência. In: Katz J,org. Tratado de Audiologia Clínica. 4a ed. São Paulo: Manole; 1999. p.403-20.

10- Kupfermann I. Localization of higher cognitive and affective functions: the association cortices. In: Kandel ER, Schwartz JH, Jessell TM. Principles of neural science. 3a ed. Connecticut: Appleton e Lange; 1991. p. 823-38.

11- Wilson JTL, Hareendran A, Grant M, Baird T, Schulz UGR, Muir KW, Bone I. Improving the assessment of outcomes in Stroke: use of a structured interview to assign grades on the Modified Rankin scale. Stroke. 2002;33:22436.
12- Jasper HA. The ten-twenty system of the International Federation. Electroencephalogr Clin Neurophysiol.1958; 10: 371-75.

13- Ferraro JA, Durrant JD. Potenciais Auditivos Evocados: Visão geral e princípios básicos. In: Katz J, org. Tratado de Audiologia Clínica. 4a ed. São Paulo: Manole; 1999. p.31535 .

14- Musiek FE, Lee WW. Potenciais auditivos de média e longa latência. In: MusieK FE, Rintelmann WF, org. Perspectivas atuais em avaliação auditiva. São Paulo: Manole; 2001. p.239-56.

15- McPherson DL. Late potencials of the auditory system (evoked potencials). San Diego: Singular Publishing Group; 1996.

16- Frizzo ACF, Alves RPC, Colafêmina JF. Potenciais evocados auditivos de longa latência: um estudo comparativo entre hemisférios cerebrais. Rev Bras Otorinolaringol. $2001 ; 67(5)$

17- Obert AD, Cranford JL. Effects of neocortical lesions on the P300 component of the auditory evoked response. Am J Otol.1990;11(6):447-53.

18- Alvarenga KF, Lamônica DC, Costa Filho OA, Banhara MR, Oliveira DT, Campo MA. Estudo eletrofisiológico do sistema auditivo periférico e central em indivíduos afásicos. Arq. Neuro Psiquiatr. 2005;63(1):104-9.

19- Schochat E. Avaliação eletrofisiológica da audição. In: Ferreira LP, Befi-Lopes D, Limongi SCO, org. Tratado de fonoaudiologia. São Paulo: Rocca; 2004. p.656-68.

20- De Renzi E, Gentilini M, Barbieri C. Auditory neglect. J Neurol Neurosurg Psychiatry.1989;52:613-7.

21-Bamiou DE, Musiek FE, Stow I, Stevens J, Cipolotti L, Brown MM, et al. Auditory temporal processing deficits in patients with insular stroke. Neurology. 2006;67:614-9.

22- Häusler R, Levine RA. Auditory dysfunction in stroke. Acta Otolaryngol. 2000;120:689-703.

13. Ferraro JA, Durrant JD. Potenciais auditivos evocados: visão geral e princípio básicos. In: Katz J (org). Tratado de Audiologia Clínica. 4a ed. São Paulo: Manole; 1999. p. 315-35. 
14. Musiek FE, Lee WW. Potenciais auditivos de média e longa latência. In: MusieK FE, Rintelmann WF, org. Perspectivas atuais em avaliação auditiva. São Paulo: Manole; 2001. p. 239-56.

15. McPherson DL. Late potencials of the auditory system (evoked potencials). San Diego: Singular Publishing Group; 1996.

16. Frizzo ACF, Alves RPC, Colafêmina JF. Potenciai evocados auditivos de longa latência: um estudo comparativo entre hemisférios cerebrais. Rev. Bras. Otorinolaringol. $2001 ; 67(5)$

17. Obert AD, Cranford JL. Effects of neocortical lesion on the P300 component of the auditory evoked response. Am. J. Otol. 1990;11(6):447-53
18. Alvarenga KF, Lamônica DC, Costa Filho OA, Banhara MR, Oliveira DT, Campo MA. Estudo eletrofisiológico do sistema auditivo periférico e central em indivíduos afásicos. Arq. Neuro Psiquiatr. 2005;63(1):104-9.

19. Schochat E. Avaliação eletrofisiológica da audição. In: Ferreira LP, Befi-Lopes D, Limongi SCO, org. Tratado de fonoaudiologia. São Paulo: Rocca; 2004. p. 656-68.

20. De Renzi E, Gentilini M, Barbieri C. Auditory neglect. J Neurol Neurosurg Psychiatry. 1989;52:613-7.

21. Bamiou DE, Musiek FE, Stow I, Stevens J, Cipolotti L, Brown MM, et al. Auditory temporal processing deficits in patients with insular stroke. Neurology. 2006;67:614-9.

22. Häusler R, Levine RA. Auditory dysfunction in stroke. Acta Otolaryngol. 2000;120:689-703. 